\title{
Banking Capital in Russia: Sufficiency, Adequacy of Market Value Evaluation
}

\section{Bondarenko V.D.}

\author{
Kazan Federal University, Institute of Management, Economics and Finance, Kazan, 420008, Russia
}

\author{
Doi:10.5901/mjss.2014.v5n24p432
}

\begin{abstract}
The article deals with the problem of insufficiency of banking capital in Russia and questions of it's market value evaluation. Insufficient capitalization of Russian banks is justified, empirical market price is calculated.
\end{abstract}

Keywords: commercial bank, market value, banking capital, stock market, gross domestic product.

The objective of this article is to justify the the problem of the insufficient capitalization of Russian commercial banks and to test the gipothesis that the market value of banking capital in Russia is underestimated.

Methods of scientific research: abstraction, synthesis of data related to separate banks and its analysis after all necessary calculations will be performed, graphic method.

After the financial crisis of 2008 the problem of the insufficient capitalization of Russian commercial banks is becoming less discussed.

Originally, problem of low capitalization and questions of adequacy of the evaluation of market value of commercial banks appeared in Russia in the late 1980s.

Since the reforms and the restructuring of Russian banking system which began in the late 1980s evaluation of the market value of banking capital was analyzed as a part of evaluation of market value of commercial bank in a whole. Russian economists investigated instruments of the process of evaluation of market value of banking capital, studied methods and approaches, upgraded them. However, holistic research of inner essence of banking capital, conceptual approach to the evaluation of the market value of banking capital wasn't developed yet.

It is quite naturally, that in 1990s the economists began investigate approaches and methods of evaluation of market value of commercial bank, because quantity of commercial banks increased rapidly in the early 1990s and reached a pick in 1997 (2,6 thousands of bank in Russia were registered). In line with growing quantity of banks Mergers and Acquisition (M\&S) market appeared. Unpredictability of Russian economics in 1990s forced economists to quickly react and to investigate the problem of low banking capital and it's evaluation.

Thus, K.A. Reshotkin created the methodology to assess the market value of the bank on the basis of management accounting data.

T.N. Mozgaleva, A.V. Zheglov and I.P. Golovina investigated practice aspects of using of approaches of market value evaluation relatively to banks.

V.M. Rutgaizer, A.E. Buditsky, I.A. Nikonova and R.N. Shamgunov as well as B.B. Leontyev and Kh.A. Mamagzhanova studied problems of evaluation of intangible assets and goodwill of banks.

I.A. Nikonova developed recommendation of using of liquidation value of bank.

A.V. Vernikov, A.A. Philippova, T.A. Vladimirova and A.A. Khlebnikov investigated practice aspects of using the comparative approach of the evaluation, proved possibilities of using different multipliers.

Almost all domestic researches used corporate financial management achievements and designs which describe conceptual foundations of the business valuation. So, Russian economists used articles and books written by R. Brealey, S. Myers, A. Damodaran, M.J. Gordon, H. Markowitz and W. Sharp.

T. Koupland, T. Koller and J. Murrin proved the possibility of using approaches and methods of evaluation previously used in corporate finances relatively to banks.

P.S. Rose, J. Sinki, J. Stern - are the key authors classified technics, approaches and methods of evaluation of the market value of banking capital.

So, there are no domestic researches related to the evaluation of market value of banking capital in Russia. Possibly, due to this for almost 30 years of the development, Russian banks are still absent among top-rated banks in international bank rankings.

For example, the international rating of the largest banks ranked by capitalization for 9 month of 2013 contains 4 
Chinese banks, only 3 from USA and no Russian banks [15].

There are no Russian banks among the largest 10 banks ranked by total assets for 2013 [9]. It should be noted, that the main quantity of banks from top 10 are also from China. France and UK banks are represented by 2 banks and the only bank from USA. First 100 banks contain 13 Chinese banks in total and only two Russian ones: Sberbank is $54^{\text {th }}$, VTB is $94^{\text {th }}$.

Intangible assets are also may be indicators which allow us to rank the largest banks. Based on the data of the most valuable banking brands for 2014 [16] we held a comparative analysis of market value of Russian and Chinese banks.

Table 1. Comparative analysis of market value of Russian and Chinese banks [16]

\begin{tabular}{|c|c|c|c|}
\hline Country & Name & Brand market value, 2014, mln USD & +/- for 2014 versus 2013, mln USD \\
\hline China & China, total & 108751 & 16099 \\
\hline \multirow{3}{*}{ Russia } & Sberbank & 10950 & -3210 \\
\cline { 2 - 4 } & VTB & 3264 & 921 \\
\cline { 2 - 4 } & Russia, total & $\mathbf{1 4 2 1 4}$ & $\mathbf{- 2 2 8 9}$ \\
\hline
\end{tabular}

Chinese banks increased its' brands market value included in top-100 by $17 \%$, while Russian banks cheaped by $13 \%$ [16]. The declining is mainly caused by cheaped Sberbank brand by 3,2 bln USD [16].

Overall, international banking ratings described are independent from each other. Its show the fact that Russian banks are still not capitalized enough. At the same time Chinese banks are aggressively grow and lead some of ratings analyzed.

In addition to ratings, values of such important indicators as bank assets/Gross Domestic Product and Banking Capital/Gross Domestic Product in Russia are much lower than western countries' values. For details, please see the graph below.

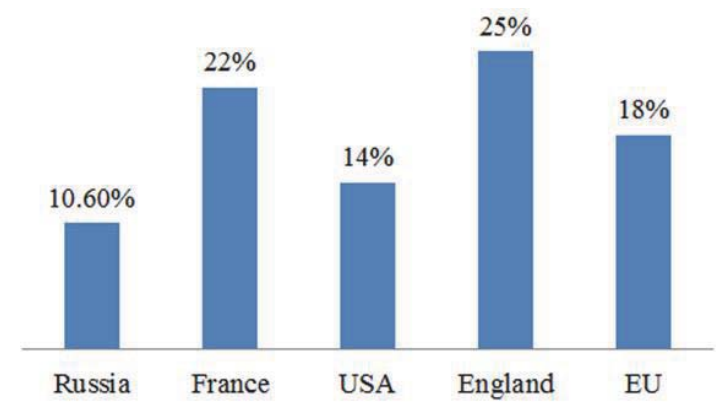

Picture 1. Bank capital/GDP by countries $[11,14]$

The value of bank capital/Gross Domestic Product is the lowest from all countries researched. Even if targeted in "Strategy of the development of the banking system until 2015" level at 14-15\% will be reached [1], Russian value will be much lower than almost all western countries.

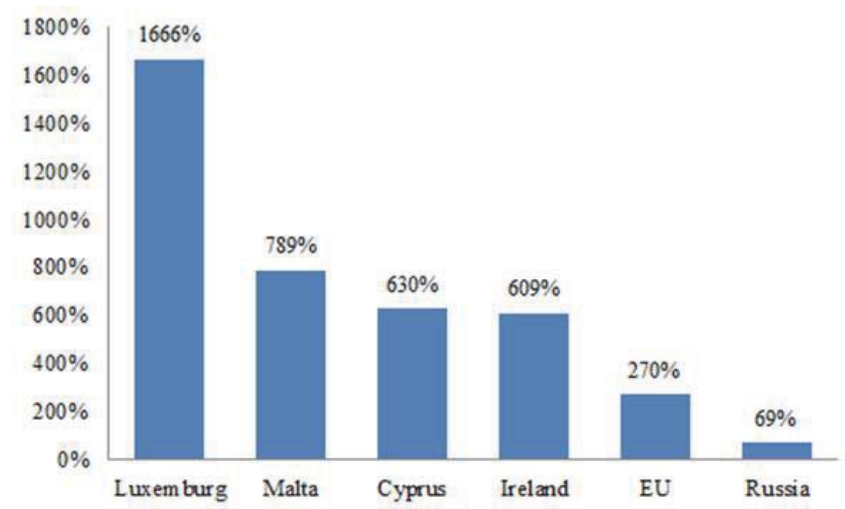

Picture 2. Banking assets/GDP by countries [2] 
The potential of growth is rather huge. To reach European Union level Russian banks' assets should be grater 4 times.

Banking capital is interacted with economics in a whole. The fact of almost the same speed of growth of banking sector and overall economics is confirmed by the following data.

Table 2. Russian and Chinese GDP for 2011-2013, bln USD [10]

\begin{tabular}{|c|c|c|c|c|c|}
\hline Country & $\mathbf{2 0 1 1}$ & $\mathbf{2 0 1 2}$ & $\mathbf{2 0 1 3}$ & Growth, bln USD & Growth, \% \\
\hline China & 11189 & 12256 & 13395 & 2206 & $19,7 \%$ \\
\hline Russia & 2363 & 2486 & 2556 & 193 & $8,1 \%$ \\
\hline
\end{tabular}

We held the comparative approach of the dynamic of Russian and Chinese GDP. As a result, we have identified that Chinese GDP increased by almost $20 \%$ for 2011-2013. This fact reflects the potential and also overall effectiveness of usage of all resources. in Russia.

Low development of economics and outflow of capital are main factors which prevent the growth of banking capital

By the way, outflow of capital is still exist even in 2000ths.

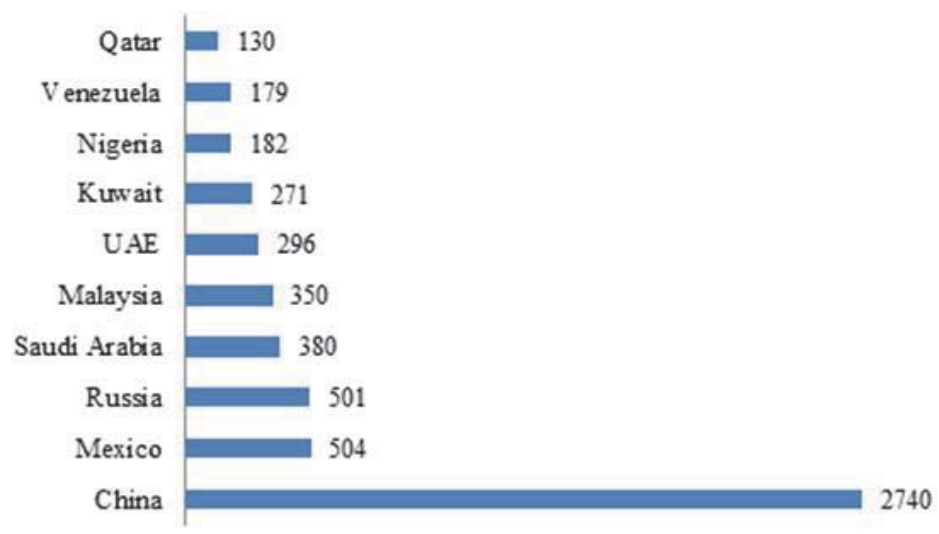

Picture 3. Volume of illegally exported capital for 2000-2009 [17]

In accordance with the picture above we see that Russia is the third country ranked by illegally exported capital. Consequently, 501 millions of USD are absent from banking sector.

Taking into account all international ratings and low volume of economic indicators described above we conclude, that the banking capital in Russia is insufficient and should be developed.

Nevertheless, it is impossible to stop the outflow of capital immediately. The process of the acceleration of economics - is long-term process. Nowadays we should use instruments that's impact on banking capital is quicker.

We assume that banking capital in Russia is underestimated on the stock market.

With the objective to test our hypothesis we will calculate the empirical market price of ordinary shares of banks listed on the Moscow exchange. We will compare calculated results with fact one.

Test of the hypothesis is held with the usage of formula $[13,210]$ :

$P=E P S \times P / E$

where $\mathrm{P}$ - empirical market price of ordinary shares;

EPS - earnings per share of bank;

P/E - price/earnings (net profit) ratio for Banks and Finances market of Moscow exchange.

The population for test includes 5 largest Russian banks listed on Moscow Exchange:

- Sberbank of Russia;

- Bank VTB;

- Bank of Moscow;

- Bank Vozrozhdenie;

- Bank Saint-Petersburg.

The period of investigation is 2010-2013. We didn't not performed extrapolation of the data for $6 \mathrm{~m}$ of 2014 due to 
unpredictability of politic situation. So, we assume, that forecasted figures for 2014 may be deviated. Moreover, since 30.06.2014 market value of ordinary shares of all analyzed banks significantly decreased. For example, the market price of shares of Sberbank of Russia declined by $14 \%$ by 30.08 .2014 .

Sources of information for the calculation:

- the official site of Moscow Exchange for stock price;

- financial statements in accordance with International Financial Reporting Standards (IFRS) for earnings per share;

- P/E ratio is calculated as average for a full calendar year.

- P/E ratio for Banks and Finances market of Moscow Exchange is calculated with accordance with following:

- ratio for market is average from banks and companies included in the calculation of Moscow Exchange index (MOEX) excluding Moscow Exchange due to its reorganization in 2011.

- if $P / E$ is below zero we use $P / E=0$;

- preferred shares are excluded from the calculation.

As a result of investigation we have calculated following amounts of P/E ratio for Banks and Finances market of Moscow Exchange:

Table 3. Calculated amounts of P/E for Banks and Finances market of Moscow Exchange for 2013-2010 [3, 4, 5, 6, 7, 8]

\begin{tabular}{|c|c|c|c|c|}
\hline Indicator/Period & 2013 & 2012 & 2011 & 2010 \\
\hline P/E & 5,7 & 11,0 & 6,4 & 26,1 \\
\hline
\end{tabular}

After that we have calculated empirical market prices of ordinary shares of banks listed and compared its with fact prices. The result of comparing is presented below.

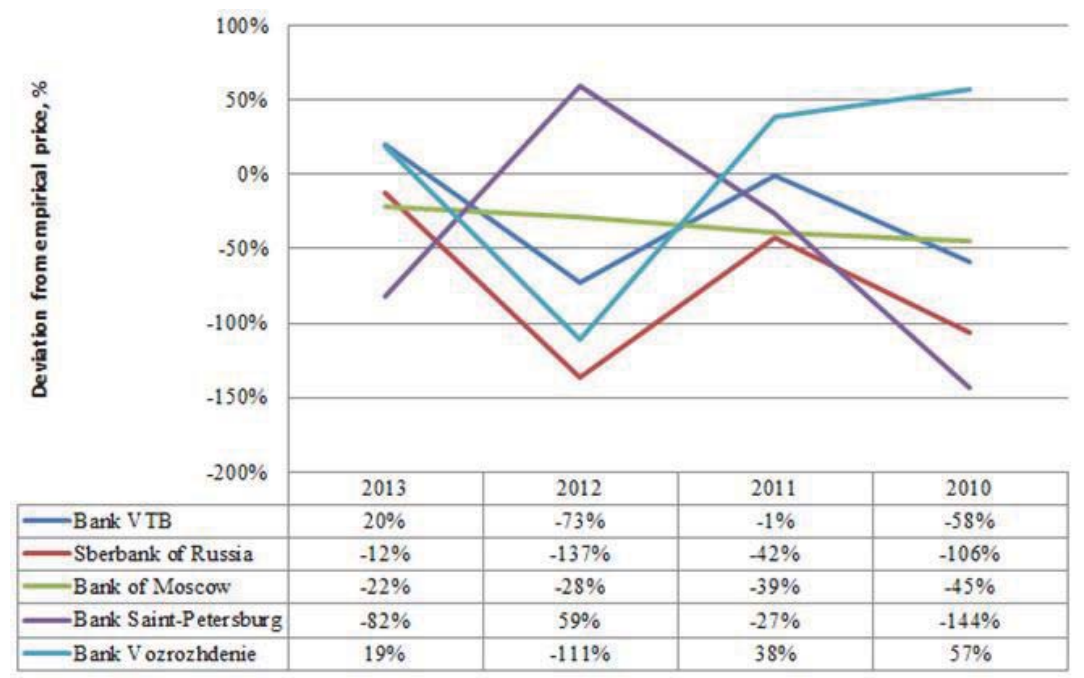

Picture 4. Deviation of market price of ordinary shares of 5 Russian banks from empirical price for 2013-2010.

Amounts below zero shows underestimated prices per share. Respectively, amount above zero - overestimated prices on the stock market.

As we can see from the data above, on 2010 ordinary shares of 4 of 5 banks were underestimated from $45 \%$ (Bank of Moscow) until 144\% (Bank Saint-Petersburg). For the period analyzed stock market systematically underestimated the real market value of banking capital of key banks listed on Moscow Exchange, as a result, the value of all Banks and Finances market is underestimated. The potential of growth is partially used for 2011-2013 and 2013 data shows that ordinary shares of Bank VTB are overestimated by $20 \%$ and shares of Bank Vozrozhdenie are overestimated by 19\%. It is should be noted, that Bank VTB's shares are overestimetsed for the first time from 2010.

Ordinary shares of Sberbank of Russia are underestimated by 12\% and amount in 2013 is the minimum for the period analyzed.

Most underestimated capital of Bank Saint-Petersburg (82\%), however this bank is not one of the largest banks in 
Russia.

The fact that such banks as Bank Saint-Petersburg and Bank Vozrozhdenie are key banks for Moscow Exchange while the largest banks are not listed on the stock market is real problem for banking sector.

The table below shows the status of top-10 Russian banks ranked by capital according to form 123 (Basel-III) on the stock market.

Table 4. Status of listing of ordinary shares of Russian largest banks on the stock market [11, 12]

\begin{tabular}{|c|l|c|c|}
\hline № & Name & Capital, billions rubles, 2014 & Ordinary shares listed on the stock-market? \\
\hline 1 & Sberbank of Russia & 2227 & Yes \\
\hline 2 & Bank VTB & 651 & Yes \\
\hline 3 & Gazprombank & 445 & No \\
\hline 4 & Rosselkhozbank & 274 & No \\
\hline 5 & VTB 24 & 246 & No \\
\hline 6 & Alfa-Bank & 223 & No \\
\hline 7 & Bank of Moscow & 192 & Yes \\
\hline 8 & Unicreditbank & 135 & No \\
\hline 9 & FC Otkritie & 116 & Yes \\
\hline 10 & Promsvyazbank & 102 & No \\
\hline
\end{tabular}

Only 4 of top-10 Russian banks conducted initial public offering (IPO) and its' shares listed on stock market. It is should be noted that total capital of top-10 banks above equals more that $60 \%$ of Russian banking sector. Due to the fact of low stock market penetration of Russian banks, investors analyzing overall Banks and Finances market, make solutions based on the limited and incomplete information. Information used is not related to all the largest banks.

Due to results obtained after the calculation performed we conclude that instruments of the evaluation of market value of banking capital should be developed with the objective to solve the problem of low capitalization of Russian banks.

The development of instruments of adequate evaluation of market value of banking capital is one of the fastest ways of the incensement of banking capital in Russia because it is related just with methodology and there is no need to wait while overall economics will be accelerated.

Results of calculation performed prove the gypothesis that the market value of banking capital of Russian banks is under estimated and the developing of instruments of it's evaluation should be developed.

Additional reserve of inreasement of banking capital is stimulating of IPO of the largest Russian banks.

\section{Refernces}

Banking sector development strategy until 2015. [Electronic resource]. Available at: http://www.consultant.ru/document/cons_doc_LAW_ 113016.

Europe is almost is almost equal to the United States. [Electronic resource]. Available at: http://www.svoboda.org/content/article/ 25157818.html.

Financial statements of AFK Sistema. Official site of AFK Sistema. [Electronic resource]. Available at: http://www.sistema.ru/ инвесторам/фринансовая-отчетность.аspх.

IFRS financial statements and financial presentations. Official site of Sberbank of Russia. [Electronic resource]. Available at: http://www.sberbank.ru/tatarstan/ru/investor_relations/accountability/fin_reports_ifrs.

IFRS financial statements of Bank VTB. Official site of Bank VTB. [Electronic resource]. Available at: http://www.vtb.ru/ir/statements.

IFRS financial statements of Bank Saint-Petersburg. Official site of Bank Saint-Petersburg. [Electronic resource]. Available at: https://www.bspb.ru/investors/financial-statements/IFRS.

IFRS financial statements of Bank Vozrozhdenie. Official site of Bank Vozrozhdenie. [Electronic resource]. Available at: http://www. vbank. ru/moscow/investors/financial.

IFRS financial statements of Bank of Moscow. Official site of Bank of Moscow. [Electronic resource]. Available at: http://www.bm.ru/ru/ir/reports/msfo.

Largest 100 banks in the world. [Electronic resource]. Available at:http://www.snl.com/InteractiveX/Article.aspx?cdid=A-2631657611566.

Official site of International Monetary fund. [Electronic resource]. Available at: http://www.imf.org/external/pubs/ft/weo/2014/01/weodata.

Official site of Bank of Russia. [Electronic resource]. Available at: http://cbr.ru.

Official site of Moscow Exchange. [Electronic resource]. Available at: http://moex.com. 
Sinki J.. Financial management in commercial banks and the financial services industry.: - M.: Alpina Publisher, 2007. - 996 p.

Terentyeva N.S. New role of the banking system // Dengi i kredit №3, 2010. p. 34-36.

Ten largest banks in the world. [Electronic resource]. Available at: http://ya-ru.ru/10-krupnejshix-bankov-mira-10-largest-banks-in-theworld.

The most valuable banking brands of 2014. [Electronic resourse]. Available at: http://brandirectory.com/league_tables/table/banking-5002014.

Tosunyan G.A. Reasons of capital outflow from Russia as a manifestation of the need for high-quality development of the financial system of the country. electronic resource. [Electronic resourse]. Available at: http://arb.ru/upload/iblock/e6e/20121217_ КонссоветЦБ_Тосунян.pdf.

Vagizova V.I. Creative for financiers. Innovatization financial infrastructure of the regional economy // Creative Economy - № 5, 2009, p. 131-139.

Vagizova V.I. Infrastructural support innovative collaboration between business, government and society in the modern economy /I Problems of Modern Economics - № 3, 2009, p. 17-22.

Vagizova, V., Lurie, K., Ivasiv, I. Clustering of Russian banks: Business models of interaction of the banking sector and the real economy. Problems and Perspectives in Management, 12 (1), pp. 83-93. 